\title{
Detection of emerging pollutants in ocean waters around king george Island, Antarctica
}

\begin{abstract}
Emerging contaminants are a wide group of compounds that include several classes of organic substances. Personal care products, pharmaceuticals, pesticides, industrial additives, monomers and plasticizers are examples of compounds included in emerging contaminants. In this work, four chemicals representing four classes of organic contaminants were investigated: salicylic acid, representing drugs; bisphenol A, a monomer widely used in the production of polymeric products; methylparaben, used as a preservative in cosmetics; and irgarol, a biocide used in agriculture and antifouling paints. A previously validated method based on liquid chromatography coupled with mass spectrometry was employed to determine the trace-levels of those compounds in ocean waters around King George Island, Antarctica. Salicylic acid and bisphenol A were found in many of the 20 samples investigated, which were collected on the northwest and southeast coasts of the island. Methylparaben and irgarol were found at low levels, each with only one occurrence. Although salicylic acid may originate in the biosynthesis of phenylalanine, the distribution and absence of this substance at some points suggest an anthropic origin. Bisphenol A was found in several sampling points, demonstrating contamination by plastics even though no correlation was found between these two compounds.
\end{abstract}

Keywords: biocide, monomer, preservative, pharmaceutical, seawater, Southern Ocean
Volume 4 Issue 5 - 2020

\author{
Maccarena Marcotti-Murua,' Felipe \\ Sotomayor-Stephens, ${ }^{2}$ Ozelito Possidonio de \\ Amarante Junior ${ }^{3,4}$ \\ 'Escuela de Medicina Veterinaria, Universidad Santo Tomás, \\ Limonares 190,Viñadel Mar,Valparaiso, Chile \\ ${ }^{2}$ Escuela de Medicina Veterinaria, Facultad de RRNN y Medicina \\ Veterinaria, Universidad Santo Tomás,Ejército 146, Santiago, \\ Chile \\ ${ }^{3}$ Departamento Acadêmico de Química, Campus São Luís - \\ Monte Castelo, Instituto Federal do Maranhão, Av. Getúlio \\ Vargas 04, Monte Castelo, 65030-004, São Luís, MA, Brasil \\ ${ }^{4}$ Instituto de Oceanografia, Universidade Federal do Rio Grande, \\ Av. Italia, km 8, Campus Carreiros, 96203-900, Rio Grande, RS,
} Brasil

Correspondence: Ozelito Possidônio de Amarante Junior, Instituto de Oceanografia, Universidade Federal do Rio Grande, Av. Italia, s/n, Campus Carreiros, 96203-900, Rio Grande, RS, Brasil,Email ozelio@ifma.edu.br

Received: May 24, 2020 | Published: September 07, 2020

\section{Introduction}

Emerging contaminants are compounds that can cause damage to the environment or to the human health but are still not monitored or have no governmental regulation. They can be from natural or synthetic origin and can include microorganisms that arrive in the environment by human action. Within synthetic chemicals, various classes can be included, which are grouped according to their chemical class or use: siloxanes, chlorinated paraffins (CPs), organophosphate esters (OPEs), perfluorinated compounds (PFCs), polybrominated compounds (PBDEs), pharmaceuticals and personal care products (PPCPs), and industrial additives are some examples. The effects of emerging contaminants to the human health and to the environment range from acute toxicity to endocrine disorders, which can result in decreased fertility in the community, low immunity and different types of cancer, to name a few examples. Another characteristic of these compounds is that due to their physical (melting and boiling point, vapor pressure, i.e.), chemical (reactivity, acid or alkaline characteristic, i.e.) and physicochemical $\left(\mathrm{K}_{\mathrm{oc}}, \mathrm{K}_{\mathrm{ow}}\right.$ and $\mathrm{K}_{\mathrm{H}}$, among others) properties, these contaminants are being found around the globe in different environmental compartments such as water, soil, atmosphere, sediment and biota. In the present work, four compounds were chosen to represent different classes of emerging contaminants: a pharmaceutical (salicylic acid, or SA), a monomer widely used in the production of polymers (bisphenol A, or BPA), a preservative (methylparaben), and a biocide used in agriculture and antifouling paints (irgarol). The chemical structures of these compounds are shown in Figure 1, and their chemical and physical properties are summarized in Table $1 .^{1-7}$
The investigated molecules have 7-15 carbon atoms and molar masses between 128 and $228 \mathrm{~g} \mathrm{~mol}^{-1}$, which is not considered very large. From their characteristics, it can be observed that SA and methylparaben are more soluble in water. All compounds have high affinity to organic phases, as indicated by their logKow values. They also have great affinity to organic carbon in the soil, which suggests these compounds accumulate in soil or sediments with high organic matter content. No Koc data was found for methylparaben.

The dissociation constants show that irgarol and salicylic acid have an acid character, dissociating at $\mathrm{pH}$ values lower than those found in seawater. It means that both substances are in anionic form that allows interactions with metallic cations insolution, especially under higher ionic forces as found in seawater. BPA and methylparaben have a slightly alkaline character, with a considerable degree of dissociation for methylparaben at $\mathrm{pH}$ around 8.0, while BPA is mostly not dissociated under marine $\mathrm{pH}$. This molecular form can increase its interaction with organic molecules such as fats and oils.

BPA is produced worldwide in large industrial quantities, as it is a constituent of polycarbonate plastics and epoxy resins used in industry and dentistry. It has been demonstrated that BPA can beingested by humans through solid food and drinking water since detectable amounts were found in food cans, microwave containers, plastic bottles, polycarbonate medical accessories, dental sealants, among other objects of daily use and universal distribution. ${ }^{8} \mathrm{BPA}$ is considered an endocrine disruptor, which is defined as "an exogenous agent that interferes with the synthesis, secretion, transport, binding, action or elimination of natural hormones that are responsible for maintaining 
homeostasis, reproduction, development and/or behavior of the individual" ${ }^{8-10}$ In experimental studies carried out with female rats, BPA caused notable reproductive and hypothalamic-pituitary changes after birth,and other responses such as the advancement of pubertal hatching, disturbances of the estrous cycle and of the pulsatility of the GnRH neuron, gonadotropic secretion and the response of certain intracellular gonadotropic messengers in response to $\mathrm{GnRH}$ were also found as the animal matures. ${ }^{11}$ Furthermore researchers found testosterone and elevated levels of estrogens in blood, low progesterone, changes in the ovarian structure with multiple cysts, and decreased fertility mimicking polycystic ovary syndrome in adults. ${ }^{12}$ In summary, Bisphenol A is a xenostrogen abundant in the environment as product of human activity, and whose toxicity greatly influences animal and human health. Its effect is more noticeable at very early ages as the perinatal organizational period, and it is persistent at

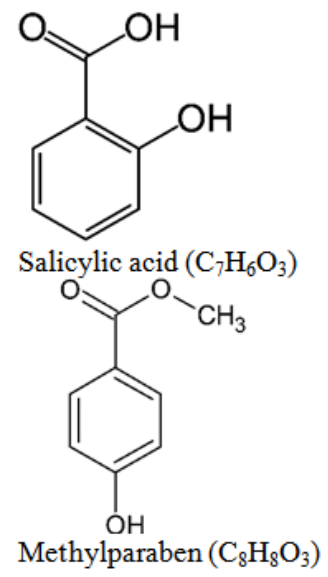

later ages. ${ }^{8}$ The biodegradability of BPA was measured by Mobil Oil Corporation using non-acclimated sewage and soil seed using a modified Sturm test that measures $\mathrm{CO}_{2}$ production. BPA was "readily" biodegradable in 28 days, as $83.6 \%$ of $\mathrm{ThCO}_{2}$ was produced. Recently, a study reported that BPA was readily biodegradable in 28 days using OECD Method 301F, known as the manometric respirometry test, achieving 81.0 to $93.1 \%$ biodegradation. They also reported extensive mineralization, with 76.3 to $90.6 \%$ of $\mathrm{ThCO}_{2}$ produced in 28 days. A 20-day study by the Dow Chemical Company reported a BOD20 of $71 \%$ of ThOD with BPA, and concluded that BPA was "readily" biodegradable by the end of that time. In contrast, two studies also using the Closed Bottle and Sturm tests with non-acclimated sewage seeds indicated insufficient degradation, concluding that BPA was not "readily" biodegradable. ${ }^{3}$<smiles>CCCCCC(C)(C)c1ccc(O[10CH2]c2ccc(O)cc2)cc1</smiles>

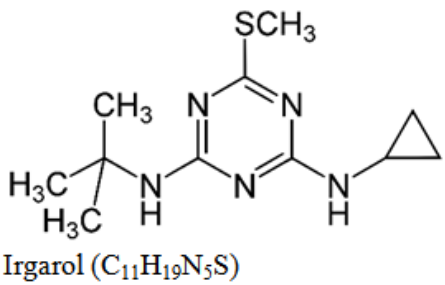

Figure I Chemical structures of the investigated compounds.

Table I Physical and chemical properties of the investigated compounds

\begin{tabular}{lllllllll}
\hline & Salicylic Acid & (Ref.) & Bisphenol A & (Ref.) & Methylparaben & (Ref.) & Irgarol & (Ref.) \\
\hline Chemical formula & $\mathrm{C}_{7} \mathrm{H}_{6} \mathrm{O}_{3}$ & 1 & $\mathrm{C}_{15} \mathrm{H}_{16} \mathrm{O}_{2}$ & 2 & $\mathrm{C}_{8} \mathrm{H}_{8} \mathrm{O}_{3}$ & 4 & $\mathrm{C}_{7} \mathrm{H}_{12} \mathrm{~N}_{5} \mathrm{~S}$ & 5 \\
Molar mass & $138.12 \mathrm{~g} \mathrm{~mol}^{-1}$ & 1 & $228.29 \mathrm{~g} \mathrm{~mol}^{-1}$ & 2 & $152.148 \mathrm{~g} \mathrm{~mol}^{-1}$ & 4 & $198.0808 \mathrm{~g} \mathrm{~mol}^{-1}$ & 5 \\
Water solubility & $2.24 \mathrm{~g} \mathrm{~L}^{-1}$ & 1 & $120-300 \mathrm{mg} \mathrm{L}^{-1}$ & 3 & $2.5 \mathrm{~g} \mathrm{~L}^{-1}$ & 4 & $7 \mathrm{mg} \mathrm{L}^{-1}$ & 7 \\
logKow & 2.26 & 1 & 3.40 & 3 & 1.96 & 4 & 4.1 & 7 \\
Koc & 35 & 1 & $314-1524$ & 3 & $*$ & & 3.14 & 7 \\
PKa & 2.98 & 1 & 9.6 & 3 & 8.5 & 4 & 4.12 & 6 \\
\hline
\end{tabular}

*Not found

The name salicylic acid (SA) comes from "Salix", a tree whose leaves and bark were used to relieve pain and fever. Johann Buchner isolated salicin in 1828 from the Salix tree, while nowadays it can be obtained industrially from carbon dioxide and sodium phenolate by electrolytic substitution and subsequent acid release from its salt by adding a strong acid, ${ }^{13}$ although it has long been suggested that SA is biosynthesized from phenylalanine. This biosynthetic pathway seems unable to account for all of the SA found in plant tissues. Alternative routes for SA formation have also been suggested based on models found in some bacteria. For example, there are bacteria that synthesize SA via chorismic acid. ${ }^{14}$ Various uses are described for SA including medicines due to its keratolytic (exfoliating) and antimicrobial properties, which are associated with its ability to promote epidermal desquamation through the breakdown of intercellular desmosomal bridges and to avoid contamination by bacteria and opportunistic fungi. A direct anti-inflammatory effect has also been attributed to SA, although this has not been confirmed yet. ${ }^{13}$ With respect to other uses (e.g. in agronomy), the application of SA induces gene expression of proteins related to increased resistance against pathogens, being considered a phytohormone. ${ }^{14} \mathrm{SA}$ is a precursor and a degradation product of acetylsalicylic acid, a widely used analgesic. ${ }^{15}$ This may be an entry route of SA into the environment. It is important to mention that SA toxicity has been associated with systemic absorption of the product when applied to the skin, causing nausea and vomiting especially in children. It also presents an antimitotic and teratogenic action, and some infrequent allergic reactions and psychic disturbances 
have been reported. ${ }^{13}$ In turn, SA has high biodegradability (1/3), with $\mathrm{pH}$-dependent biotic degradation (test BOD5 $=0.95 \mathrm{~g} \mathrm{~g}^{-1}$; ThOD $1,623 \mathrm{~g} \mathrm{~g}^{-1} ; \mathrm{COD}=$ D.100 D\% ThOD). ${ }^{16}$

Methylparaben (methyl p-hydroxybenzoate) is amethyl ester of p-hydroxybenzoic acid used as a preservative in chemical, pharmaceutical and food industries. ${ }^{17}$ It is obtained by esterification (Fischer reaction) from p-hydroxybenzoic acid and methanol in the presence of an acid catalyst such as sulfuric acid. Parabens have properties that gives them various applications. One of the most notable is their high bacteriostatic and fungistatic activities against numerous microorganisms even in low concentrations, which is why their application as preservatives have been proposed for food, pharmaceuticals, cosmetics, textiles, among other products..$^{18}$ Several investigations have been carried out to study the toxicity of parabens in the environment. These have shown that they have relatively low toxicity, showing mild estrogenic activity. ${ }^{19}$ This toxicity may be due to the parabens themselves or to their metabolites. Some parabens are intrinsically toxic but they can have effects due to bioaccumulation or bioamplification of cellular receptors. Also, the persistence or degradation of these substances in the environment can alter their toxicity. Escribano, 2019, evaluated different experimental methods with 4 parabens and showed that methyl paraben had the lowest toxicity since higher amounts of this paraben is needed to produce the effects on the organisms. ${ }^{20}$

Irgarol is used in the formulation of antifouling paints, that aim to prevent the growth of organisms on submerged surfaces. ${ }^{21,22}$ It is a symmetric triazine that blocks a reaction in the electronic transport chain of photosystem II. ${ }^{23-25}$ Although the use of this product is authorized, prolonged contact with water can lead to the leaching of these compounds and subsequently to their entry into the food chain, with risks to the organisms and to the environment. As expected, many studies showed that Irgarol is highly toxic to aquatic plants. Previous studies reported that chronic toxicity was observed in selected communities of periphyton and seawater algae related to Irgarol exposurein concentration ranges of $60-250 \mathrm{ng} \mathrm{L}^{-1}$ and 600 5900ng L $\mathrm{n}^{-1}$, respectively. Furthermore, this biocide is persistent in the marine environment, with a half-life for irgarol-1051 between 100 and 350days. ${ }^{26}$

The objective of this research was to conduct a prospective study to identify emerging contaminants in ocean waters around the King George island, where research bases from different countries are located. The present work also aims to contribute to the knowledge of this type of contamination and to alert the scientific community and governments about the need for monitoring and control of these and other substances, since they reach places that are distant from where they are produced and mainly consumed.

\section{Experimental part}

\section{Reagents}

Salicylic acid was bought from United States Pharmacopeia (USP, USA). Methylparaben was provided by Fiocruz (Fundação Oswaldo Cruz, Brazil). Bisphenol A and irgarol were bought from Sigma Aldrich (Brazil).

Acetonitrile, methanol, toluene and acetone (HPLC grade) were bought from J.T. Baker (USA). Hexyl acetate and octanol were supplied by Sigma Aldrich (Brazil). Magnesium sulfate (anhydrous,
$\mathrm{MgSO}_{4}$ ) was purchased from J.T Baker (Mexico), whereas sodium chloride was bought from Merck (Germany). Calcium chloride, sodium hydroxide and ammonium sulfate were provided by Synth (Brazil). Glacial acetic acid and hydrochloridric acid were obtained from Merck (Germany). The water was purified by an Ultrapure Water System (USA).

\section{Apparatus and software}

The chromatographic system consisted of a Waters Alliance 2695 Separation Module (Waters, Milford, MA, USA), an automatic sampler, a membrane degasser and a quaternary pump. Mass spectrometry was performed in a Micromass Quattro Micro API (Waters, Milford, MA, USA) with an electrospray interface (ESI). Nitrogen was used as the nebulization gas, generated by pressurized air in a Genius NM32LA nitrogen generator (Peak Scientific). The nebulizer gas flow was 50L $\mathrm{h}^{-1}$, while the desolvation gas flow was $550 \mathrm{~L} \mathrm{~h}^{-1}$. To MS/MS mode operation, the collision gas used was argon $99.99 \%$ (White Martins, Brazil) with a pressure of $3.5 \times 10^{-3} \mathrm{mbar}$ in the collision cell. Optimized values were: $4.0 \mathrm{kV}$ for capillary voltage; $2 \mathrm{~V}$ for extractor voltage; $100{ }^{\circ} \mathrm{C}$ for source temperature; $400{ }^{\circ} \mathrm{C}$ for desolvation temperature; and $650 \mathrm{~V}$ for multiplier voltage. Collision energies were optimized for each compound, aiming to get two characteristic multiple reaction monitoring (MRM) transitions with the best signal intensity. After that optimization, two different precursor ion-product ion transitions were selected for quantification and confirmation of each compound. Analytical instrument control, data acquisition and treatment were performed by the MassLynxsoftware (Micromass, Manchester, UK), version 4.1 .

Chromatographic separation was carried out in a Kinetex C8 column $(3.0 \mathrm{~mm}$ x $50 \mathrm{~mm}$ i.d., $2.6 \mu \mathrm{m}$ film thickness) by Phenomenex (USA). Mobile phase components, with elution in the gradient mode, were (A) ultrapure water with $0.1 \%$ acetic acid and (B) methanol. Initial composition was $20 \% \mathrm{~B}$; it was increased linearly to $90 \%$, in 20 $\mathrm{min}$, held until $23 \mathrm{~min}$, and returned to the initial composition in $0.5 \mathrm{~min}$ and held for $6.5 \mathrm{~min}$, totaling a $30 \mathrm{~min}$ analysis. Flow rates were: 0-20min, $0.2-0.4 \mathrm{~mL} \mathrm{~min}^{-1}$; 20-23min, $0.4 \mathrm{~mL} \mathrm{~min}^{-1} ; 23-23.5 \mathrm{~min}, 0.4-$ $0.2 \mathrm{~mL} \mathrm{~min}^{-1} ; 23.5-30 \mathrm{~min}, 0.2 \mathrm{~mL} \mathrm{~min}^{-1}$. Injection volume was $10 \mu \mathrm{L}$. These optimized conditions were followed exactly as described by Caldas and coworkers. ${ }^{27}$ Method validation was carried out by those authors. Limit of Quantification (LOQ) was $0.25 \mathrm{ug} \mathrm{L}^{-1}$ for salicylic acid, bisphenol A and methylparaben. LOQ was $0.0125 \mathrm{ug} \mathrm{L}^{-1}$ for irgarol. Recoveries ranged between 79 to $117 \%$, for bisphenol A; 103 and $116 \%$ for salicylic acid; 84 and $112 \%$ for methylparaben; and 77 to $114 \%$ for irgarol. Relative standard deviations were under $19 \%$. Recovery studies were carried out in 7 different fortification levels ranged between 0.0125 to $12.5 \mathrm{ug} \mathrm{\textrm {L } ^ { - 1 }}$.

\section{Sample collection and treatment}

A prospective study was carried out analyzing 20 samples of 100 $\mathrm{ml}$ obtained from the water on beach shore and collected at different points on King George Island. Sampling dates, locations and observed activities are shown in Table 2. For the transfer from the sampling area to the INACH laboratory, water samples were collected in $100 \mathrm{~mL}$ sterile plastic bottles, with screw caps. Within 5hours after taking the samples, they were filtered through a MN-616 filter paper (MachereyNagel) and subsequently through Strata $\mathrm{C} 18-\mathrm{E}(55 \mu \mathrm{m}, 70 \mathrm{~A})$ solid phase extraction (SPE) cartridgesat a flow of approximately $1 \mathrm{~mL} \mathrm{~min}$ ${ }^{1}$. SPE cartridges were conditioned by eluting with $5 \mathrm{~mL}$ of methanol followed by $5 \mathrm{~mL}$ of ultrapure water. 
Table 2 Sampling locations and observed activities

\begin{tabular}{|c|c|c|c|c|c|}
\hline Sample & $\begin{array}{l}\text { Sampling } \\
\text { date }\end{array}$ & $\begin{array}{l}\text { Location and } \\
\text { Replicate } \\
\text { number }\end{array}$ & LATITUDE & LONGITUDE & Observed activities \\
\hline E I & $02 / 01 / 2016$ & Elefanteras I & $62^{\circ} 11.808^{\prime}(S)$ & $58^{\circ} 59.676^{\prime}(O)$ & $\begin{array}{l}\text { Area exposed to the Drake Sea with a high presence of marine } \\
\text { wildlife, mainly represented by elephant seals (Mirounga leonina). } \\
\text { Little human activity, both marineand land based. }\end{array}$ \\
\hline E 2 & $02 / 01 / 2016$ & Elefanteras 2 & $62^{\circ} 11.973^{\prime}(S)$ & $58^{\circ} 00.063^{\prime}(O)$ & $\begin{array}{l}\text { Area exposed to the Drake Sea with a high presence of marine } \\
\text { wildlife, mainly represented by elephant seals (Mirounga leonina). } \\
\text { Little human activity, both marine and land based. }\end{array}$ \\
\hline II & $30 / 11 / 2015$ & Istmo I & $62^{\circ} 12.483^{\prime}(S)$ & $58^{\circ} 57.332^{\prime}(\mathrm{O})$ & $\begin{array}{l}\text { Bahía Fildes area. Sampling performed close to human activities, } \\
\text { due to its location between Villa las Estrellas and China Great } \\
\text { Wall Base. Reduced presence of wildlife, represented mainly by } \\
\text { sea birds and the Weddell seal. }\end{array}$ \\
\hline 12 & $30 / 11 / 2015$ & Istmo 2 & $62^{\circ} 12.483^{\prime}(S)$ & $58^{\circ} 57.332^{\prime}(\mathrm{O})$ & $\begin{array}{l}\text { Bahía Fildes area. Sampling performed close to human activities, } \\
\text { due to its location between Villa las Estrellas and China Great } \\
\text { Wall Base. Reduced presence of wildlife, represented mainly by } \\
\text { sea birds and the Weddell seal. }\end{array}$ \\
\hline C I & $21 / 12 / 2015$ & Carlini I & $62^{\circ} 23.947^{\prime}(S)$ & $58^{\circ} 68.029^{\prime}(O)$ & Nearby human activities due to the presence of Base Carlini \\
\hline C 2 & $21 / 12 / 2015$ & Carlini 2 & $62^{\circ} 23.616^{\prime}(\mathrm{S})$ & $58^{\circ} 65.959^{\prime}(\mathrm{O})$ & Nearby human activities due to the presence of Base Carlini \\
\hline C 3 & $21 / 12 / 2015$ & Carlini 3 & $62^{\circ} 23.261(\mathrm{~S})$ & $58^{\circ} 61.350^{\prime}(\mathrm{O})$ & $\begin{array}{l}\text { Nearby human activities due to the presence of Base Carlini. } \\
\text { Sample collection near the port (zodiacs). }\end{array}$ \\
\hline (I) PR I & $12 / 12 / 2015$ & (I) Pryroda I & $62^{\circ} 09.316^{\prime}(\mathrm{S})$ & $58^{\circ} 56.26 \mathrm{I}^{\prime}(\mathrm{O})$ & $\begin{array}{l}\text { High presence of wildlife. Away from both land and marine based } \\
\text { human activities. Area exposed to marine currents, with great } \\
\text { presence of garbage of human origin brought by currents. }\end{array}$ \\
\hline (I) PR 2 & $12 / 12 / 2015$ & (I) Pryroda 2 & $62^{\circ} 09.320^{\prime}(\mathrm{S})$ & $58^{\circ} 56.210^{\prime}(\mathrm{O})$ & $\begin{array}{l}\text { High presence of wildlife.Away from both land and marine based } \\
\text { human activities. Area exposed to marine currents, with great } \\
\text { presence of garbage of human origin brought by currents. }\end{array}$ \\
\hline (2)PRI & $04 / 01 / 2016$ & (2) Pryroda I & $62^{\circ} 09.03 I^{\prime}(S)$ & $58^{\circ} 56.486^{\prime}(\mathrm{O})$ & $\begin{array}{l}\text { High presence of wildlife. Away from both land and marine based } \\
\text { human activities. Area exposed to marine currents, with great } \\
\text { presence of garbage of human origin brought by currents. }\end{array}$ \\
\hline (2)PR 2 & $04 / 01 / 2016$ & (2) Pryroda 2 & $62^{\circ} 09.104^{\prime}(S)$ & $58^{\circ} 56.41 I^{\prime}(O)$ & $\begin{array}{l}\text { High presence of wildlife. Away from both land and marine based } \\
\text { human activities. Area exposed to marine currents, with great } \\
\text { presence of garbage of human origin brought by currents. }\end{array}$ \\
\hline (2)PR3 & $04 / 01 / 2016$ & (2) Pryroda 3 & $62^{\circ} 09.372^{\prime}(\mathrm{S})$ & $59^{\circ} 56.225^{\prime}(\mathrm{O})$ & $\begin{array}{l}\text { High presence of wildlife. Away from both land and marine based } \\
\text { human activities.Area exposed to marine currents, with great } \\
\text { presence of garbage of human origin brought by currents. }\end{array}$ \\
\hline (2)PR 4 & $04 / 01 / 2016$ & (2) Pryroda 4 & $62^{\circ} 09.320^{\prime}(\mathrm{S})$ & $58^{\circ} 56.210^{\prime}(\mathrm{O})$ & $\begin{array}{l}\text { High presence of wildlife. Away from bothland and marine based } \\
\text { human activities. Area exposed to marine currents, with great } \\
\text { presence of garbage of human origin brought by currents. }\end{array}$ \\
\hline (2)PR5 & $04 / 01 / 2016$ & (2) Pryroda 5 & $62^{\circ} 09.525^{\prime}(\mathrm{S})$ & $58^{\circ} 56.699^{\prime}(\mathrm{O})$ & $\begin{array}{l}\text { High presence of wildlife. Away from both land and marine based } \\
\text { human activitiesArea exposed to marine currents, with great } \\
\text { presence of garbage of human origin brought by currents. }\end{array}$ \\
\hline C I & $30 / 11 / 2015$ & Costa I & $62^{\circ} 12.019^{\prime}(\mathrm{S})$ & $58^{\circ} 59.700^{\prime}(\mathrm{O})$ & $\begin{array}{l}\text { High presence of wildlife. Away from both land and marine based } \\
\text { human activities. Area exposed to marine currents }\end{array}$ \\
\hline C 2 & $30 / 11 / 2015$ & Costa 2 & $62^{\circ} 12.482^{\prime}(\mathrm{S})$ & $58^{\circ} 57.328^{\prime}(\mathrm{O})$ & $\begin{array}{l}\text { High presence of wildlife. Away from both land and marine based } \\
\text { human activities. Area exposed to marine currents. }\end{array}$ \\
\hline C 3 & $08 / 12 / 2015$ & Costa 3 & $62^{\circ} 10.710^{\prime}(\mathrm{S})$ & $58^{\circ} 59.075^{\prime}(\mathrm{O})$ & $\begin{array}{l}\text { High presence of wildlife. Away from bothland and marine based } \\
\text { human activities. Area exposed to marine currents. }\end{array}$ \\
\hline C 4 & $08 / 12 / 2015$ & Costa 4 & $62^{\circ} 10.714^{\prime}(S)$ & $58^{\circ} 59.145^{\prime}(\mathrm{O})$ & $\begin{array}{l}\text { High presence of wildlife. Away from both, land and marine } \\
\text { human activity. Area exposed to marine currents }\end{array}$ \\
\hline C 5 & $08 / 12 / 2015$ & Costa 5 & $62^{\circ} 10.675^{\prime}(\mathrm{S})$ & $58^{\circ} 58.90 \mathrm{I}^{\prime}(\mathrm{O})$ & $\begin{array}{l}\text { High presence of wildlife. Away from both land and marine based } \\
\text { human activities. Area exposed to marine currents. }\end{array}$ \\
\hline C 6 & $08 / 12 / 2015$ & Costa 6 & $62^{\circ} \mathrm{I} 2.483^{\prime}(\mathrm{S})$ & $58^{\circ} 57.332^{\prime}(0)$ & $\begin{array}{l}\text { High presence of wildlife. Away from both land and marine based } \\
\text { human activities. Area exposed to marine currents. }\end{array}$ \\
\hline
\end{tabular}


Once the extraction was completed, SPE cartridges were dried at room temperature and then frozen at $-4^{\circ} \mathrm{C}$ until laboratory analysis. The samples were sent in an express parcel service inside a cooler containing gel packs to Federal University of the Rio Grande (FURG), where the liquid chromatography with coupled mass spectrometry (LC/MS) analysis were carried out as described. Before analysis, cartridges were washed with ultrapure water prior to elution to remove soluble salts. Analytes were eluted with $6 \mathrm{~mL}$ of methanol, dried under a stream of nitrogen and reconstituted with $1 \mathrm{~mL}$ of methanol/water (50:50).

\section{Statistical analysis}

Data obtained in this investigation were treated with the R Software using the "vegan" package. ${ }^{28-29}$

\section{Results}

Data of analyte concentration found around King George Island are shown in Table 3. Methylparaben was detected only at a sampling point where we observed a high presence of endemic fauna, without any terrestrial or marine human activities. This area is under the influence of strong marine currents, with a large presence of marine solid waste brought by them. Marine litter can be the source of this preservative, since it can be found in cosmetics, food and pharmaceutical products. ${ }^{30-31}$ Irgarol was also detected only at a sampling point close to zodiacs port zodiacs, with human activities due to the presence of the Carlini Base. This compound can be part of antifouling paints on ships and other submerged surfaces.

Table 3 Sampling locations and emergent pollutants detected

\begin{tabular}{|c|c|c|c|c|c|c|c|}
\hline \multirow{2}{*}{ Coast } & \multirow{2}{*}{$\begin{array}{l}\text { Sample } \\
\text { identification }\end{array}$} & \multirow{2}{*}{ LATITUDE } & \multirow{2}{*}{ LONGITUDE } & Salicylic acid & Bisphenol A & Methylparaben & Irgarol \\
\hline & & & & \multicolumn{4}{|l|}{$\left(\mathbf{m g ~ L} \mathbf{L}^{-1}\right)$} \\
\hline NW & E I & $62^{\circ} 11.808^{\prime}(S)$ & $58^{\circ} 59.676^{\prime}(O)$ & ND & ND & ND. & ND \\
\hline NW & E 2 & $62^{\circ} 11.973^{\prime}(S)$ & $58^{\circ} 00.063^{\prime}(O)$ & 0.003 & 0.003 & ND & ND \\
\hline SE & II & $62^{\circ} 12.483^{\prime}(\mathrm{S})$ & $58^{\circ} 57.332^{\prime}(O)$ & 0.003 & 0.001 & ND & ND \\
\hline SE & 12 & $62^{\circ} 12.483^{\prime}(\mathrm{S})$ & $58^{\circ} 57.332^{\prime}(O)$ & 0.002 & 0.001 & ND & ND \\
\hline SE & C I & $62^{\circ} 23.947^{\prime}(\mathrm{S})$ & $58^{\circ} 68.029^{\prime}(O)$ & 0.002 & 0.001 & ND & ND \\
\hline SE & $C 2$ & $62^{\circ} 23.616^{\prime}(\mathrm{S})$ & $58^{\circ} 65.959^{\prime}(\mathrm{O})$ & 0.005 & 0.001 & ND & ND \\
\hline SE & $C 3$ & $62^{\circ} 23.26 \mathrm{I}(\mathrm{S})$ & $58^{\circ} 61.350^{\prime}(O)$ & 0.003 & 0.001 & ND & 0.0001 \\
\hline NW & (I)PR I & $62^{\circ} 09.316^{\prime}(\mathrm{S})$ & $58^{\circ} 56.26 I^{\prime}(O)$ & ND & 0.001 & ND & ND \\
\hline NW & (I)PR 2 & $62^{\circ} 09.320^{\prime}(\mathrm{S})$ & $58^{\circ} 56.210^{\prime}(O)$ & 0.004 & 0.001 & ND & ND \\
\hline NW & (2)PRI & $62^{\circ} 09.03 \mathrm{I}^{\prime}(\mathrm{S})$ & $58^{\circ} 56.486^{\prime}(O)$ & 0.005 & ND & ND & ND \\
\hline NW & (2)PR 2 & $62^{\circ} 09.104^{\prime}(\mathrm{S})$ & $58^{\circ} 56.4 \mathrm{II}^{\prime}(\mathrm{O})$ & 0.007 & 0.005 & 0.001 & ND \\
\hline NW & (2)PR3 & $62^{\circ} 09.372^{\prime}(S)$ & $59^{\circ} 56.225^{\prime}(O)$ & 0.003 & ND & ND & ND \\
\hline NW & (2)PR 4 & $62^{\circ} 09.320^{\prime}(\mathrm{S})$ & $58^{\circ} 56.210^{\prime}(O)$ & ND & 0.008 & ND & ND \\
\hline NW & (2)PR5 & $62^{\circ} 09.525^{\prime}(S)$ & $58^{\circ} 56.699^{\prime}(O)$ & 0.003 & 0.003 & ND & ND \\
\hline NW & C I & $62^{\circ} 12.019^{\prime}(S)$ & $58^{\circ} 59.700^{\prime}(O)$ & 0.003 & 0.001 & ND & ND \\
\hline NW & $C 2$ & $62^{\circ} 12.482^{\prime}(\mathrm{S})$ & $58^{\circ} 57.328^{\prime}(\mathrm{O})$ & 0.001 & ND & ND & ND \\
\hline NW & C 3 & $62^{\circ} 10.710^{\prime}(S)$ & $58^{\circ} 59.075^{\prime}(O)$ & 0.004 & ND & ND & ND \\
\hline NW & C 4 & $62^{\circ} 10.714^{\prime}(S)$ & $58^{\circ} 59.145^{\prime}(O)$ & 0.005 & 0.001 & ND & ND \\
\hline NW & C 5 & $62^{\circ} 10.675^{\prime}(S)$ & $58^{\circ} 58.90 I^{\prime}(O)$ & 0.011 & 0.247 & ND & ND \\
\hline NW & C 6 & $62^{\circ} 12.483^{\prime}(\mathrm{S})$ & $58^{\circ} 57.332^{\prime}(O)$ & 0.007 & 0.109 & ND & ND \\
\hline
\end{tabular}

$N D=$ Not detected - we were not able to detect a peak 3 times bigger than the noise on baseline

Concentrations of bisphenol A and salicylic acid are presented in Figure 2. For this figure, outliners were removed for better visualization. Data were randomly dispersed in relation to longitude and latitude, but there was no significant correlation between concentration and geographical position. 


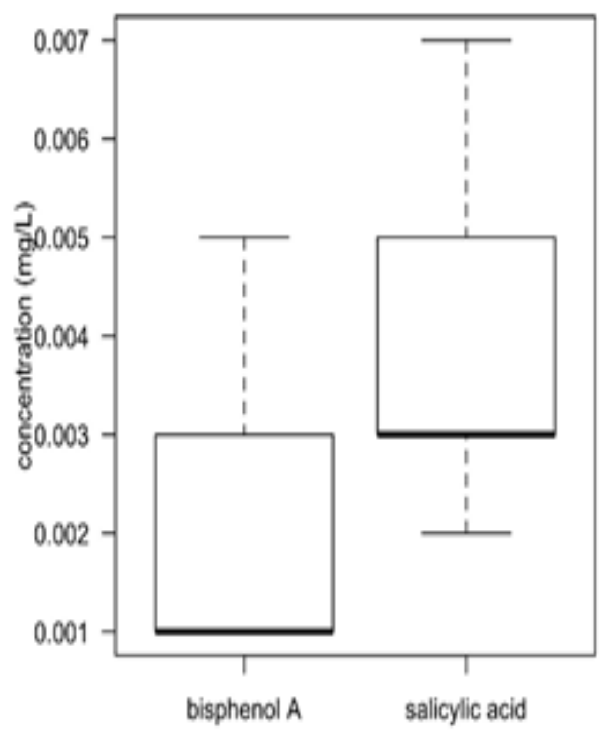

Figure 2 Contaminants concentration found in this investigation, without outliners.

\section{Discussion}

This study discovered seawater contamination by four organic contaminants from different chemical groups around George Island. This type of investigation can justify further studies about contamination levels and their sources, whether diffuse or punctual This study will help researchers to uncover critical areas of emerging pollutants' presence, source, fate and effects, which was not able to be explored at this time. Thus, a new theory on dynamics and fate of products of anthropogenic origin in Antarctica may be developed. Salicylic acid was detected in many samples ranging from 0.001 to $0.011 \mathrm{mg} \mathrm{L}^{-1}$. The highest concentration was observed in point a distant from any terrestrial or marine human activities, but with high presence of native wildlife while exposed to sea currents. These currents may be the source of this contaminant, since salicylic acid is present in PPCPs and is synthesized by plants, but we have not found any native species in Antarctica reported as a source of salicylic acid. This contaminant was not detected in three sampling points: two without human activities but with a large amount of marine litter; and one with few human activities. Bisphenol A was detected in the range of 0.001 to $0.008 \mathrm{mg} \mathrm{L}^{-1}$, but two samples showed higher levels of this compound: 0.109 and $0.247 \mathrm{mg} \mathrm{L}^{-1}$. Both points were distant from human activities and under the influence of sea currents. This contaminant was not detected in five sampling points with different characteristics: in very clean areas but also in areas with a large amount of marine litter.

BPA is a monomer widely distributed in environmental compartments due to its common use in polymers production. ${ }^{32}$ Caldas et al. analyzed58 pesticides, pharmaceuticals and personal care products employing solvent demulsification dispersive liquid-liquid microextraction combined with liquid chromatography coupled with tandem mass spectrometry. They detected salicylic acid at the level of $1.67 \mu \mathrm{g} \mathrm{L}^{-1}$, bisphenol A between 0.418 and $4.42 \mu \mathrm{g} \mathrm{L}^{-1}$, methylparaben between 0.32 and $0.805 \mu \mathrm{g} \mathrm{L}^{-1}$, and irgarol at $0.25 \mu \mathrm{g} \mathrm{L}^{-1}$ in surface waters sampled ofRio Grande, in the state of Rio Grande do Sul, southern Brazil, in two seasons. ${ }^{27}$ These concentrations are higher than those found in the present study. It is noteworthy that samples analyzed by those researchers were collected in or near a city, with great human activity, unlike the samples collected in the Southern Ocean which are far from human settlements and their economic activities. It is important to remember that investigations have already been carried out on the contribution of scientific research bases to the contamination of waters and sediments in Antarctica. Emnet and collaborators researched PPCPs and hormones from sewage discharges from two research stations. Bisphenol A, hormones and PPCPs were found in effluents at higher values than those found in previous studies. They also found bisphenol A, methylparaben and other emerging contaminants in seawater and sea ice. Methylparaben was found to be preferentially accumulating in biota, especially fish. ${ }^{33}$ This may justify the absence of this contaminant in 19 of the 20 samples analyzed in the present study.

\section{Conclusion}

This prospective study was able to identify emerging contaminants in seawater off the coast of King George Island. Some sampling points were impacted by marine litter and others were far from human activities. We found contamination at different locations, supporting the need for further investigation of more substances and indifferent seasons. This work was an initial contribution to the knowledge about this type of contamination. A monitoring and control program for these substances can enrich the understanding of the fate and behavior of emerging contaminants in that sensitive environment. Studies involving physical aspects such as the influence of sea currents and the extent of the contamination plume, and factors such as exchanges between the solid (sediment), liquid and gaseous (atmosphere) phases, bioaccumulation, biomagnification and toxicity in the context of the Antarctic polar environment are necessary, since they differ greatly from the conditions where other investigations have been performed. The main challenges for future studies involve the logistics of conducting sampling and analysis in extreme weather conditions and the physical distance from our laboratories. Organized expeditions or opportunity cruises have contributed to an increasing number of studies in Antarctica, but much remains to be done in order to better understand the effect of these new compounds produced for the convenience of contemporary human life.

\section{Acknowledgments}

We are grateful to the Laboratório de Análises de Compostos Orgânicos e Metais (LACOM) of Universidade Federal do Rio Grande for their relevant contribution carrying out chromatographic analysis. We are also grateful the Chilean Antarctic Institute (INACH), the Chilean Post Office and the Chilean Air Force for their support in both transferring and accommodation in King George Island.

\section{Conflicts of interest}

None.

\section{References}

1. Popova L, Pancheva T, Uzunova A. Salicylic Acid: Properties, biosynthesis and physiological role. Bulg J Plant Physiol. 1997;23:85-93.

2. Jalal N, Surendranath A, Pathak J, et al. Bisphenol A (BPA) the mighty and the mutagenic. Toxicol Rep. 2018;5:76-84.

3. Staples C, Dorn P, Klecka G, et al. A review of the environmental fate, effects, and exposures of bisphenol A. Chemosphere. 1998;36(10):21492173 
4. Puerta YT, Guimarães PS, Martins SE, et al. Toxicity of methylparaben to green microalgae species and derivation of a predicted no effect concentration (PNEC) in freshwater ecosystems. Ecotox environ safe. 2020;30(188):109916.

5. Ferrer I, Fernandez-Alba A, Zweingenbaum J, et al. Exact-mass library for pesticides using a molecular-feature database. Rapid commun mass sp. 2006;20(24):3659-3668.

6. Saleh A, SheijooniFumani N, Molaei S. Microfunnel-supported liquidphase microextraction: Application to extraction and determination of Irgarol 1051 and diuron in the Persian Gulf seawater samples. $J$ Chromatogr A. 2014;1356:32-37.

7. Diniz LG, Jesus M, Dominguez LA, et al. First Appraisal of Water Contamination by Antifouling Booster Biocide of 3rdGeneration at Itaqui Harbor (São Luiz - Maranhão - Brazil). J Braz Chem Soc. 2014;25(2):380-388.

8. Bourguignon N, Fernandez M, Lux-Lantos V, et al. Neuroendocrine alterations by endocrine disruptors: the example of Bisphenol A. Acta Bioquím Clín Latinoam. 2011;45(4):599-719.

9. Daston GP, Cook JC, Kavlock RJ. Uncertainties for Endocrine Disrupters: Our View on Progress. Toxicol Sci. 2003;74(2):245-252.

10. Diamanti-Kandarakis E, Bouguinon J, Guidice LC, et al. EndocrineDisrupting Chemicals: An Endocrine Society Scientific Statement. Endocr Rev. 2009;30(4):293-342.

11. Fernandez MO, Bianchi MS, Lux-Lantos V, et al. Neonatal Exposure to Bisphenol A Alters Reproductive Parameters and Gonadotropin Releasing Hormone Signaling in Female Rats. Environ Health Perspect. 2009;117(5):757-762.

12. Fernandez MO, Bourguignon N, Lux-Lantos V, et al. Neonatal exposure to bisphenol $\mathrm{A}$ and reproductive and endocrine alterations resembling the polycystic ovarian syndrome in adult rat. Environ Health Perspect. 2010;118(9):1217-1222.

13. Cuellar L, Sehtman A, Donatti L, et al. Ácido Salicílico. Act Terap Dermatol. 2008;31:108.

14. Jordán M, Casaretto J. Fisiología vegetal. Edicionesuniversitarias de La Serena, La Serena, Chile. 2006. 16.

15. De Aguiar JLN, Leandro KC, Abrantes SDMP, et al. Development of a new analytical method for determination of acetylsalicylic and salicylic acids in tablets by reversed phase liquid chromatography. Braz J Pharm Sci. 2009;45(4):723-727.

16. Panreac. Ficha de datos de seguridad según reglamento. (CE) 1907/2006.

17. Eastmond Gallego, John Henry. Obtención de Metilparabeno y Propilparabeno a partir de acido salicílico. Saru.afe de Bogota; Memoria para tesis de grado de Ingeniero Químico. Fundación Universidad de América. Facultad de ingeniería. 1990.

18. Galeano H, Rodríguez G, Correa N, et al. Ensayo comparativo de tres catalizadores enlaproducción de metil parabeno. Ingeniería $e$ Investigación. 1996;25:2-10.
19. Routledge E, Parker J, Odu J, et al. Some Alkyl Hydroxy Benzoate Preservatives (Parabens) Are Estrogenic. Toxicol and Appl Pharmacol. 1998;153(1):12-19.

20. Escribano N. Estudio de biodegradabilidad de una mezcla de parabenos para planta de depuración biológica acoplada a tratamiento de ozono. Memoria para tesis de grado de Ingeniería Química. Universidad Politécnica de Valencia. 2019

21. Gimeno RA, Aguilar C, Marcé RM, et al. Monitoring of antifouling agents in water samples by on-line solid-phase extraction-liquid chromatography-atmospheric pressure chemical ionization mass spectrometry. J Chromatogr A. 2001;915(1-2):139-147.

22. Piedra L, Tejedor A, Hernando MD, et al. Screening of antifouling pesticides in sea water samples at low ppt levels by GC-MS and LC-MS Chromatographia. 2000;52(9-10):631-638.

23. Gatidou G, Kotrikla A, Thomaidis NS, et al. Determination of the antifouling booster biocides irgarol 1051 and diuron and their metabolites in seawater by high performance liquid chromatography-diode array detector. Anal Chim Acta. 2005;528(1):89-99.

24. Sheikh MA, Juma FS, Staehr P, et al. Occurrence and distribution of antifouling biocide Irgarol-1051 in coral reef ecosystems, Zanzibar. Mar Pollut Bull. 2015;109(1):586-590.

25. Lambert SJ, Thomas KV, Davy AJ. Assessment of the risk posed by the antifouling booster biocides Irgarol 1051 and diuron to freshwater macrophytes. Chemosphere. 2006;63(5):734-743.

26. Plá J. Desarrollo de metodologías sostenibles de análisis. Tesis Doctoral. Universitat de Valencia. Facultat de Química. 2007.

27. Caldas SS, Rombaldi C, De Oliveira Arias JL, et al. Multi-residue method for determination of 58 pesticides, pharmaceuticals and personal care products in water using solvent demulsification dispersive liquid-liquid microextraction combined with liquid chromatography-tandem mass spectrometry. Talanta. 2016;146:676-688.

28. R Core Team. R: A language and environment forstatistical computing. $\mathrm{R}$ Foundation for StatisticalComputing, Vienna, Austria. 2019.

29. Oksanen J, Kindt R, Simpson GL. The vegan Package. Community Ecology Package, Version 1.15-1. 2008

30. Kroflič A, Apelblat A, Bešter-Rogač M. Dissociation Constants of Parabens and Limiting Conductances of Their Ions in Water. J Phys Chem B. 2012;116(4):1385-1392.

31. Liao C, Liu F, Kannan K. Occurrence of and Dietary Exposure to Parabens in Foodstuffs from the United States. Environ Sci Technol. 2013;47(8):3918-3925.

32. Corrales J, Kristofco LA, Baylor Steele W, et al. Global Assessment of Bisphenol A in the Environment: Review and Analysis of Its Occurrence and Bioaccumulation. Dose-Response. 2015;13(3):1559325815598308.

33. Emnet P, Gaw S, Northcott G, et al. Personal care products and steroid hormones in the Antarctic coastal environment associated with two Antarctic research stations, McMurdo Station and Scott Base. Environ Res. 2015;136:331-342. 